Научная статья

УДК 130.2:001

DOI: $10.18101 / 1994-0866-2021-2-79-85$

\title{
СТАНОВЛЕНИЕ ДЕФИНИЦИИ «ТРАДИЦИЯ»
}

\section{(C) Трегулова Наталья Петровна}

кандидат искусствоведения, доцент кафедры народной музыки, Институт национальной культуры МГУ им. Н. П. Огарева, доцент Саранской духовной семинарии Россия, 430016, г. Саранск, ул. Полежаева, 44/3 natali-tregulova@yandex.ru

\begin{abstract}
Аннотация. Традиция является важнейшей категорией целого ряда наук и научных направлений, тем не менее единого общепринятого определения этого понятия не существует. В статье рассматриваются различные подходы ученых к дефиниции «традиция». Многообразие подходов в исследовании этого феномена обусловлено его многоаспектностью, предметной и методологической спецификой исследующих данное явление наук. Автор статьи проводит анализ различных подходов к проблеме традиции, раскрывает эволюцию взглядов на роль традиции в обществе и в науке.

Автор подчеркивает большой вклад отечественной культурологической и философской школы в процесс исследования феномена «традиция». Традиция обычно изучается как динамичное и развивающееся явление, имеющее большое значение для нормального функционирования общества в работах второй половины XX в. - С. А. Арутюнова, Б. В. Власовой, В. Д. Плахова. Философская точка зрения на понятие «традиция» отражена в трудах западных мыслителей - Х.-Г. Гадамера, Г. Гегеля, интерпретируется социологом Дж. Томпсоном, а также современными российскими социологами А. Б. Гофманом и С. В. Лурье.

Ключевые слова: герменевтика, дефениция «традиция», научные традиции, связь настоящего с прошлым, традициология, феномен традиции
\end{abstract}

\section{Для цитирования}

Трегулова Н. П. Становление дефиниции «традиция» // Вестник Бурятского государственного университета. Философия. 2021. Вып. 2. С. 79-85.

В истории науки и культуры процесс осмысления понятия «традиция» был достаточно противоречивым. Дефиниция «традиция» и в настоящее время является узловой точкой искусствоведческих и культурологических дискуссий, в результате которых так и не разработан единый подход к определению этого понятия. Существуют также различные точки зрения на название области науки, которая должна изучать феномен традиции: с точки зрения российского философа Э. С. Маркаряна это традициология, по мнению В. Д. Плахова - традициеведение. Российский социолог А. Б. Гофман [7] подчеркивает, что попытка придать официальный статус учению о традиции свидетельствует о важности этой области знаний, но название само по себе еще не говорит об окончательном формировании этого учения. Польский исследователь проблемы традиции, историк и философ Е. Шацкий также указывает, что «в современной литературе мы имеем 
довольно широко распространенное убеждение в необходимости теории традиции, но не имеем такой теории» [9, с. 208].

Рассмотрим авторские подходы к определению «традиция». Основатель философской герменевтики Х.-Г. Гадамер писал, что «...по существу своему традиция - это сохранение того, что есть, сохранение, осуществляющееся при любых исторических переменах» [3, с. 334]. Американский социолог П. Штомпка считает традицией «...совокупность тех объектов и идей, истоки которых коренятся в прошлом, но которые можно обнаружить в настоящем, то есть это все то, что не было уничтожено, выброшено и разбито. В данном случае традиция равносильна наследию - тому, что реально сохранилось от прошлого...» [цит. по: 5, с. 174]. Российский историк и социальный антрополог С. А. Арутюнов [1] определяет традицию как передачу всего, что образует костяк культуры, новым поколениям. Автор подчеркивает, что традиция как явление изначально присуще человеку, так как зачаточные формы традиции наблюдаются у высших приматов и других общественных животных. Философ и социолог В. Д. Плахов считал, что «...по своей сущности традиция есть отношение, общественное отношение, отличающееся определенной устойчивостью, повторяемостью, общностью» [6, с. 35]. В. Б. Власова [2] утверждает, что механизм традиции действует в двух направлениях: с одной стороны, он схематизирует различные формы человеческой деятельности путем их перевода в категорию идеальных нормативных установок. С другой стороны, он превращает эти нормативные установки в исходные программы деятельности за счет их воспроизведения последующими поколениями. Е. Шацкий [9] считает, что все существующие в научной литературе определения традиции можно разделить на три категории. Первый вид определений, функциональный, сводит традицию к межпоколенческой передаче тех или иных ценностей. В центре второго вида, объектного, находится сущность передаваемых ценностей, а третий, субъектный, говорит об отношении к этим ценностям того поколения, которому они передаются.

Для более полного раскрытия феномена «традиция» ученые определили ряд функций, которые выполняют в обществе различные традиции. По мнению В. С. Чернышёва [8], важнейшей функцией традиции следует считать обеспечение устойчивости системы общественных отношений, их регенерацию в настоящем и будущем. Важной функцией исследователь считал также воспитательную функцию, выдвинутую на первый план советским государством в соответствующий исторический период. Обязательная преемственность поколений тем не менее не означала полное копирование предшествующего опыта. В этом советская идеология была солидарна с К. Марксом и Ф. Энгельсом, которые считали, что человечество постоянно движется вперед, поэтому новое поколение, с одной стороны, должно критически относиться к опыту предшественников, а с другой - не может обойтись без базовых ценностей, созданных прошлыми поколениями. Подчеркивая важность определения функций традиции, Плахов указывает, что именно в функциях, в их системном назначении, проявляется действительное бытие традиций. Ученый говорит о необходимости различать общие (родовые) и специфические (видовые) функции традиции. Общие функции имеют в основе закономерности, которые прослеживаются во всех традициях без 
исключения. Важнейшей общей функцией традиции автор считает обеспечение устойчивости отношений в обществе, в чем оказывается солидарен с Чернышёвым.

Среди общих функций Плахов выделяет функцию фиксации общественных отношений, так как в традиции они закрепляются и переходят в устойчивое состояние. Он говорит также об упорядочивающей функции, благодаря которой общественные отношения структурируются и приводятся в определенную систему регламентирующей, или ограничительной, функции, функиии социальной связи. Традиция выполняет также информационную функцию, так как, по сути, является «специфическим средством накопления, хранения и передачи социальной информации» $[6$, c. 102]. В традиции информация в концентрированном виде может сохраняться веками, воплощая коллективную память общества, аккумулируя и консервируя социальный опыт. Еще одной функцией традиции является конструирование и конституирование социума, посредством которой любое общество утверждается исторически и регионально. С этой функцией, по мнению Плахова, связана функция презентащии и репрезентащии социумов. В этом случае традиция является визитной карточкой того или иного общества. К общим функциям автор относит функиию соџиализаџии, благодаря которой индивид приобщается к социальному опыту. Видовые функции связаны с теми сферами, в рамках которых они реализуются. В искусстве традиция выполняет эстетическую функцию; в религиозной области - компенсаторную; в научных исследованиях - гносеологическую. Частные функции работают в системе межчеловеческого общения и служат основаниями действий субъекта. Автор выделяет эвокативную, стимуляционную функцию, которая побуждает человека к определенным действиям. С ней тесно связана функция фасцинации, благодаря которой отдельный индивид «затягивается», примыкает к какому-либо социальному объединению. Традиции также успешно выполняют функцию социального контроля поведения людей. Таким образом, Плахов приходит к выводу о том, что традиция многофункциональна, и эта тема требует дополнительных глубоких исследований.

Английский социолог Дж. Томпсон [10] говорит о четырех аспектах традиции, которые могут трактоваться как ее функции. Герменевтическая функиия способствует передаче способа восприятия мира, его интерпретации, приданию ему смысла. Функция легитимаџии и нормативная определяют меру дозволенного. Идентификащионная функция определяет чувство принадлежности к той или иной системе ценностей. Помимо различных функций А. Б. Гофман [7] предлагает различать также разновидности самой традиции, что помогает глубже понять этот феномен. К примеру, традищия-инерция воспроизводит сложившийся порядок вещей. Традищия-реставрация восстанавливает далекое прошлое. Традищия-оболочка преподносит старое содержание в новом облике, а традищияностальгия способствует восприятию прошлого как лучшего времени.

Философия также не выработала единого взгляда на концепцию традиции, несмотря на то, что различные варианты учения о традиции зародились многие тысячелетия назад. Анализируя подходы к традиции в истории философии, В. Д. Плахов [6] писал, что еще в философской системе древнего китайского 
мыслителя Конфуция (479 г. до н. э.) понятие традиции занимало важное место. В философии Древней Греции оно было частью понятия «этос», которое означало, с одной стороны, привычку, а с другой — человеческий нрав. В это время был заложен подход к этосу как к духовному проявлению, идеальной форме, который затем долгое время господствовал в науке.

Один из создателей немецкой классической философии Г. Гегель в своих рассуждениях о традиции четко разделял факты реальной зависимости от традиций прошлого и отношение новых поколений, которые принимают образцы прошлого или отрицают их. По мнению философа, диалектический подход к отрицанию старого предполагает выделение той рациональной части традиции, которая способствовала ее закреплению в прошлом. Рассуждая о традиции, Гегель подчеркивал ее динамическую сторону, ее способность расти и изменяться «подобно могучему потоку» $[4$, с. $10-11]$. Та часть традиции, которая наследуется в поколениях, становится их духовным богатством, их привычными принципами.

Представители герменевтики, одного из философских направлений XX в., Х.-Г. Гадамер и П. Рикёр видели в традиции не поддающиеся рефлексии «предрассудки», которые обеспечивают понимание процессов, происходящих в обществе. Понимание какого-либо «предания» дает индивиду опыт социальной практики и приводит к самоосмыслению. Но любая интерпретация осуществляется на основе традиции, которая, в свою очередь, есть не что иное, как интерпретация этой традиции. Гадамер подчеркивал также, что традиция - это точка пересечения истории и свободы и формируется она не только естественным путем, но в условиях согласия и заботы. «По существу своему традиция - это сохранение того, что есть, сохранение, осуществляющееся при любых исторических переменах. <..> Даже там, где жизнь меняется стремительно и резко, как, например, в революционные эпохи, при всех видимых превращениях сохраняется гораздо больше старого, чем полагают обыкновенно, и это старое господствует, объединяясь с новым в новое единство», - писал философ [3, с. 334-335].

Современному немецкому философу В. Хёсле принадлежит теория рефлексивной истории традиции, суть которой состоит в том, что любой исследователь традиции является одновременно и наблюдателем, и ее «персонажем». При этом он может не только усовершенствовать, но и изменить традицию. В этой теории смысловой вектор направлен не в прошлое, как в подавляющем большинстве теорий традиции, а в будущее. Многие авторы и источники выделяют также ценностный аспект понятия «традиция». В «Современном философском словаре» подчеркивается, что традиция является особой разновидностью «...исторического сознания двойственной природы - повествуя о том, "что и как" было в истории... она одновременно возводит это "что и как" в ранг исторической нормы, преобразует факты прошлого в абсолютные ценности современности» ${ }^{1}$. Там же указывается, что осознание традиции как социального факта связано с ценностной интерпретацией традиции.

\footnotetext{
${ }^{1}$ Современный философский словарь. 4-е изд. Москва: Академический проект; Екатеринбург: Деловая книга, 2015. С. 720.
} 
Часто ценностный аспект традиции нагружается эмоциональным содержанием. Как подчеркивает Е. Шацкий, фактически в истории не было периода нейтрального отношения к традиции - это понятие либо нагружалось сверхценностью, либо обесценивалось. Человеческие сообщества и отдельных людей объединяет приверженность или враждебность по отношению к тем или иным традициям. «Одни усматривают в традиции бельмо на глазах человечества, другие считают традицию глазами человечества», - пишет Шацкий. Это происходит потому, что «и те, и другие видят в традиции не столько факт, сколько ценность» [9, с. 210]. Ученый приводит в пример слова французского психолога, социолога и антрополога Г. Лебона, который, с одной стороны, считал традицию, «подлинной предводительницей народов», но с другой - называл ее «единственным действительным тираном человечества» [цит. по: 9, с. 211].

Статус сверхценности традиция получает также в традиционализме. Парадоксально, но идея сверхценности традиции возникла как логическое продолжение полного отрицания традиции, начавшегося в эпоху Просвещения. Характерно также, что Просвещение, противопоставившее традицию разуму и прогрессу, было традиционным по сути, так как, отрицая традиции Средневековья, оно опиралось на традиции более далекого прошлого. В противоположность этому крайнему подходу родилась другая крайность - апология традиции. Представители нового течения обвиняли Просвещение в разрушении устоявшихся социальных норм и утверждении анархии в обществе. Традиционалисты отрицали приоритет разума в формировании общества и выдвигали на первый план религию, веру и традицию. Традиция, по их мнению, наделена высшей мудростью. Она соединяет в себе вековое наследие и божественную волю. Ограниченный человеческий разум не всегда способен постичь эту мудрость, тем не менее традиция всегда имела и будет иметь фундаментальное значение в социальной жизни. С точки зрения традиционалистов, традиции - это опора общества, их необходимо сохранять и культивировать. В противном случае общество ждет экономическая и нравственная деградация и постепенное разрушение.

Если для отечественной науки положения о динамичном характере традиции и взаимосвязи традиции и инновации были нормой, то подходы к изучению феномена традиции в мировой науке начали меняться с 60-х гг. XX в. Традиция перестала рассматриваться как застывшая или отмирающая форма, препятствующая прогрессу и присущая в основном традиционным обществам. Примечательно, что новый подход был заложен в исследованиях востоковедов и африканистов, изучивших те самые традиционные общества, где, по мнению большинства, господствовала консервативная традиция. Ученые, в частности исследователи восточных обществ Л. Пай, Л. Деспрэ и др., подвергли сомнению тезис о статичности традиционного общества и самой традиции, который долгое время был универсальной истиной. Было выдвинуто предположение, что традиция имеет внутреннюю, относительно неизменную сторону, и внешнюю, подверженную изменениям. Поэтому при всей своей универсальности устойчивость традиций имеет предел. Традиция и новация, ранее полярно разводившиеся, оказались диалектически связанными. Но, несмотря на определенное единодушие относительно взаимосвязи традиции и новации, ученые так и не пришли к единому 
мнению в подходах к существу феномена традиции. Как подчеркивает С. В. Лурье [5], разброс мнений относительно определения сущности понятия «традиция〉 и в настоящее время очень велик. К примеру, современный американский социолог Ф. Риггс обосновал популярную концепцию переходного общества, где традиция фактически создала свой собственный механизм самовоспроизводства, обнаруживая большие адаптивные возможности и приспосабливаясь к быстроменяющимся условиям. Традиционные ценности в этом случае не только не отрицаются, но и становятся средством достижения новой цели. Этнолог А. Ройс предложил заменить понятие «традиция» понятием «исторический стиль». Для исторического стиля характерны общие характеристики и ценности, но при этом он гибок и вариативен. И прошлое, и настоящее можно оценивать как внешнее проявление этого пластичного и гибкого феномена. Другие ученые настаивают на сохранении термина «традиция». Один из крупнейших исследователей традиции американский социолог Э. Шилз считает, что традиция не вырабатывается и не воспроизводится сама по себе и следовать традиции означает создавать непрерывную цепь вариаций на тему, заданную предыдущими поколениями. Носители традиции всегда стремятся создать нечто лучшее, чем прошлые поколения.

Таким образом, традиция играет большую роль в историческом процессе, она является необходимым условием существования и стабильности общества. Но в истории отношение к традиции было весьма противоречивым, при этом для обществ, где традиция главенствовала, не была характерна рефлексия о ней. Первые попытки научного осмысления традиции были сделаны в Новое время, которое, как ни парадоксально, отражало самые противоречивые взгляды на этот феномен.

Аналогичные процессы происходили в науках, изучавших феномен традиции, - социологии, философии. Большой разброс авторских подходов характеризовался перевесом мнений о консервативном характере традиции. Возникновение термина «традиционное общество», которому противопоставлялось современное, инновационное, отражало эти взгляды.

Процесс осмысления традиции в отечественной науке был своеобразен: идеологическая окраска исследований не привела к отрицанию диалектического характера традиции. Отечественные ученые были единодушны в своем подходе к традиции как к динамическому явлению, способному к изменению и развитию.

Лumepamypa

1. Арутюнов С. А. Народы и культуры. Развитие и взаимодействие. Москва: Наука, 1989. 247 с. Текст: непосредственный.

2. Власова В. Б. Традиция как социально-философская категория // Философские науки. 1980. № 4. С. 30-39. Текст: непосредственный.

3. Гадамер Х.-Г. Истина и метод: основы философской герменевтики. Москва: Прогресс, 1988. 704 с. Текст: непосредственный.

4. Гегель Г. Собрание сочинений: в 14 томах. Москва: Партийн. изд-во, 1932. Т. 9. 490 с. Текст: непосредственный.

5. Лурье С. В. Историческая этнология. Москва: Аспект Пресс, 1997. 448 с. Текст: непосредственный. 
6. Плахов В. Д. Традиции и общество: опыт философско-социологического исследования. Москва: Мысль, 1982. 220 с. Текст: непосредственный.

7. Традиции и инновации в современной России. Социологический анализ взаимодействия и динамики / под редакцией А. Б. Гофмана. Москва: РОССПЭН, 2008. 544 с. Текст: непосредственный.

8. Чернышёв В. С. Традиции, обряды в системе формирования идеалов личности. Киев: Вища школа, 1986. 144 с. Текст: непосредственный.

9. Шацкий Е. Утопия и традиция. Москва: Прогресс, 1990. 456 с. Текст: непосредственный.

10. Thompson J. B. Tradition and Self in a Mediated World // Detraditinalization. Critical Reflections on Authority and Identity / Ed. by P. Heelas, S. Lash and P. Morris. Cambridge (Mass.); Oxford: Blackwell, 1996. P. 89-108. Текст: непосредственный.

Статья поступила в редакциию 03.03.2021; одобрена после рецензирования 30.03.2021; принята к публикации 11.05.2021.

\section{FORMATION OF THE “TRADITION” DEFINITION}

Natalya P. Tregulova

Cand. Sci. (Art History), A/Prof. of Folk Music Department, Institute of National Culture, Ogarev Mordovian State University

A/Prof. of Saransk Theological Seminary

44/3 Polezhaeva St., Saransk 430016, Russia

natali-tregulova@yandex.ru

Abstract. Tradition is the important category of a number of sciences and disciplines, however there is no a universally accepted definition of this concept. The article discusses various scientific approaches to the definition of "tradition". Their variety is conditioned by the multidimensionality, the specific subject and methods for studying this phenomenon. We have analyzed various approaches to the concept of "tradition", traced the evolution of views on the role of tradition in society and science.

We emphasize the great contribution of the national cultural and philosophical school to the process of studying the phenomenon of "tradition". In the works of the second half of the twentieth century by S. A. Arutyunov, B. V. Vlasova, V. D. Plakhov tradition is usually considered as a dynamic and developing phenomenon of great importance for proper functioning of society. The philosophical point of view on the concept of "tradition" is reflected in the works of Western thinkers H.-G. Gadamer, G. Hegel, it is interpreted by a sociologist J. Thompson, as well as by contemporary Russian sociologists A. B. Hoffman and S. V. Lourié.

Keywords: hermeneutics, definition of "tradition", scientific traditions, relationship of the present and the past, traditiology, phenomenon of tradition

\section{For citation}

Tregulova N. P. Formation of the "Tradition" Definition. Bulletin of Buryat State University. Philosophy. 2021; 2: 79-85 (In Russ.).

The article was submitted 03.03.2021; approved after reviewing 30.03.2021; accepted for publication 11.05.2021. 